\title{
PERAN DU PONT SYSTEM GUNA MENINGKATKAN PRESTASI KINERJA KEUANGAN KUD PAMEKASAN
}

\author{
Moh. Herman Djaja \\ hermandj@unira.ac.id \\ Wahyu Maulana \\ Universitas Madura
}

\begin{abstract}
Initially the financial statements were only in the form of "testing tools" of the performance of a company's bookkeeping. However, as its development is used as a basis for determining or assessing the company's financial position. These results are obtained by analyzing where the development is used as a basis for decision making. Where the results of the analysis is a picture of the company's performance carried out periodically. From this description, the stakeholders can find out the good or bad of the company's financial condition. The object of research is the entire KUD Pamekasan district. The purpose of this study was to determine whether KUD's financial performance was efficient, measured using the du pont system. This type of research is quantitative descriptive. This research was conducted using the method of direct observation to the field. The research resulted that out of 13 KUDs in Pamekasan, there were 5 that were still active while 8 others were no longer active both in terms of their activities and management. Of the active KUDs, the best financial performance analysis results are the KUD Karya Bakti Pakong while the other KUDs need an increase in performance so that the financial condition is better
\end{abstract}

Key words: cooperatives; $d u$ pont systems and financial performance achievements

\begin{abstract}
ABSTRAK
Awalnya laporan keuangan hanya berupa"alat penguji" kinerja sebuah pembukuan perusahaan saja. Namun, seiring perkembangannya digunakan sebagai dasar untuk menentukan atau menilai posisi keuangan perusahaan. Hasil tersebut diperoleh dengan cara menganalisisnya dimana pada perkembangan yang belum memenuhi standardnya digunakan dasar pengambilan keputusan. Dimana hasil analisisnya merupakan gambaran kinerja perusahaan yang dilaksanakan secara periodik. Dari gambaran tersebut, para pihak yang berkepentingan dapat mengetahui baik buruknya kondisi keuangan perusahaan. Obyek penelitian merupakan seluruh Koperasi Unit Desa (KUD) Kabupaten Pamekasan. Tujuan penelitian untuk mengetahui apakah kinerja keuangan KUD sudah efesien, diukur menggunakan $d u$ pont system. Jenis penelitiannya adalah deskriptif kuantitatif. Penelitian ini dilakukan menggunakan metode observasi langsung ke lapangan. Adapun penelitian ini menghasilkan bahwa dari 13 KUD di Pamekasan, terdapat 5 yang masih aktif sedangkan 8 lainnya sudah tidak aktif baik dari segi aktivitas maupun kepengurusannya. Dari KUD yang aktif, hasil analisis kinerja keuangan paling baik adalah KUD Karya Bakti Pakong sedangkan KUD lainnya perlu adanya peningkatan kinerja agar kondisi keuangan lebih membaik.
\end{abstract}

Kata kunci: koperasi; du pont system dan prestasi kinerja keuangan

\section{PENDAHULUAN}

Perusahaan memiliki laporan keuangan kebanyakan hanya berupa sebagai "alat penguji" dari kinerja sebuah pembukuan perusahaan namun selanjutnya seiring perkembangannya laporan keuangan di- gunakan sebagai dasar untuk menentukan atau menilai posisi keuangan sebuah perusahaan jadi tidak hanya sebagai alat penguji saja. Hasil tersebut diperoleh dengan menganalisis laporan keuangan agar bermanfaat bagi banyak pihak yang selanjutnya 
digunakan pula sebagai dasar pengambilan suatu keputusan oleh perusahaan tidak terkecuali juga apa yang terjadi pada koperasi. Hasil analisis tersebut merupakan gambaran kinerja sebuah perusahaan atau koperasi yang rutin dilaksanakan secara periodik (Saraswati et al., 2013) dan dari gambaran tersebut, para pihak yang berkepentingan dapat mengetahui baik buruknya kondisi perusahaan tersebut yang tentunya dilihat dari segi kinerja keuangannya (Soegiarto, 2018).

Negeri ini sangat banyak bentuk perusahaan dan terus berkembang seiring perkembangan zaman. Terdapat 3 (tiga) sektor bentuk usaha formal diantaranya BUMN (Badan Usaha Milik Negara), sektor swasta dan koperasi. Untuk BUMN meliputi: perbankan, asuransi, industri dan masih banyak yang lainnya. Untuk sektor swasta, dimana usaha ini tujuannya mencari untung yang sebesar-besarnya dan menjadikan modal sebagai faktor utamanya sedangkan untuk koperasi, yakni sebuah badan usaha kerakyatan yang salah satu tujuannya yakni mensejahterakan kehidupan masyarakat pada umumnya. Koperasi merupakan sebuah bentuk badan usaha, juga penting menerapkan analisis laporan keuangannya. Pentinganya analisis laporan keuangan koperasi diantaranya: untuk menilai pertanggungjawaban pengurus; menilai sejauh mana prestasi kerja pengurus dan koperasi itu sendiri; menilai manfaat koperasi terhadap anggotanya; serta untuk mengetahui jumlah sumber daya, karya, jasa yang telah diberikan oleh koperasi tersebut sebagai bahan pertimbangannya dimana hal tersebut merupakan bentuk evaluasi sebuah koperasi dalam hal mencapai sebuah tujuannya (Utami et al., 2015).

Metode untuk menganalisis laporan keuangan perusahaan diantaranyaanalisis CAMEL (capital, assets quality, management, earning and liquidity), analisis BSC (balanced scorecard), analisis du pont system, analisis MVA (market value added) dan analisis EVA (economic value added), analisis rasio keuangan hingga metode DLA (Development
Ladder Assessment) yang dapat dipergunakan untuk mengukur kinerja koperasi yang terdiri dari 4 (empat) variabel diantaranya yakni: visi, sumber daya, kapasitas dan jaringan (Haryadi dan Rahab, 2006). Rasio keuangan merupakan alat analisis yang sering digunakan perusahaan dimana perusahaan dapat berfokus pada penggunaan rasio profitabilitas dan aktivitas yang pada penggunaannya kedua rasio tersebut untuk mengukur kinerja keuangan perusahaan pada tingkat efisiensi dan efektivitas (Phrasasty et al., 2015). Kedua rasio tersebut termasuk ke dalam indikator rasio rentabilitas dimana dapat dipergunakan pula untuk mengukur kinerja perusahaan melalui analisis $d u$ pont system yang merupakan alat pemberi informasi akan faktor penyebab kinerja perusahaan yang fluktuatif dengan melihatkan hubungan antara keuntungan, aset serta investasi yang dipergunakan untuk pengembalian modal perusahaan (Tarmizi dan Marlim, 2016).

Untuk mewujudkan terciptanya hasil analisis yang baik dan sesuai dengan standar, maka perlu upaya secara khusus dan didukung dengan tersedinya suatu perangkat penilaian koperasi yang jelas, terperinci, sederhana dan bersifat menyeluruh. Dalam meningkatkan serta terus memantapkan usaha koperasi yang telah dilakukan maka koperasi perlu analisis, integrasi dan penilaian untuk menetapkan ukuran kinerja dalam rangka menumbuh kembangkan segala kegiatannya serta dapat menyesuaikan dengan tingkat pertumbuhan koperasi dewasa ini. Sebagai badan usaha, koperasi harus mampu meningkatkan efisiensi kerja sesuai dengan prinsip-prinsip ekonomi, namun koperasi harus tetap berpegang pada prinsip koperasi yaitu demokratis sesama anggota (Novianti, 2005). Dengan menciptakan kinerja khususnya kinerja keuangan yang baik, akan dapat diciptakan pula sebuah strategi yang baik pula baik itu melalui strategi analisis SWOT ataupun dengan melalui strategi lainnya demi pengembangan koperasi yang lebih maju dimasa yang akan mendatang 
(Febrinova, 2013). Hasil dari penelitian terdahulu terkait dengan kinerja keuangan koperasi dengan menggunakan berbagai macam alat analisis diantaranya: penelitian yang dilakukan oleh Sagala et al., (2012); penelitian yang dilakukan oleh Mbae (2013); penelitian yang dilakukan oleh Sarjana et al., (2013); penelitian dari Andani et al., (2015); penelitian yang dilaksanakan oleh Kurniawan dan Mulyapradana (2018) serta penelitian dari Yusuf (2016). Yang menjadi pembeda atau keunikan dari hasil penelitian ini adalah alat analisis yang digunakan merupakan alat analisis yang jarang bahkan belum pernah digunakan oleh peneliti sebelumnya sehingga hasil penilaian kinerja KUD di Pamekasan yang merupakan obyek dari penelitian ini akan menghasilkan kinerja keuangan dari sudut pandang yang berbeda sehingga akan menambah atau memperkaya keilmuan di bidang kinerja keuangan pada KUD atau koperasi pada jenis usaha lainnya.

Laporan keuangan berupa neraca dan laporan laba rugi yang bersumber dari RAT (Rapat Anggota Tahunan) dipergunakan sebagai data penelitian yang nantinya dipergunakan untuk dianalisis dengan menggunakan analisis du pont system. Untuk lebih memfokuskan penelitian ini, maka peneliti membatasi masalah sebagai berikut: Data laporan keuangan yang dianalisis menggunakan du pont system berupa laporan keuangan 3 (tiga) tahun terakhir yakni 2015 - 2017; dan obyek yang diteliti adalah KUD di Kabupaten Pamekasan yang masih aktif.

Tujuan penelitian yang akan dilakukan oleh penulis adalah untuk mengetahui apakah kinerja keuangan KUD di seluruh Kabupaten Pamekasan yang dianalisis menggunakan $d u$ pont system mengalami peningkatan?

\section{TINJAUAN TEORETIS Koperasi}

Menurut UU No. 17 tahun 2012 menyatakan bahwa koperasi merupakan badan yang dibentuk oleh sekelompok orang yang berbadan hukum dengan menjalankan usahanya tersebut dengan melakukan pemisahan kekayaannya serta dapat menjalankan nilai dan prinsip koperasi untuk memenuhi kebutuhan aspirasi bersama. Koperasi merupakan sebuah lembaga dengan bentuk usaha dan pelayanan yang mempunyai peran dalam membantu anggotanya secara khusus serta masyarakat secara umum dan keberadaannya sangat diperlukan (Huda et al., 2017). Koperasi merupakan bentuk perusahaan yang paling sesuai dengan demokrasi ekonomi Indonesia seperti yang terkandung dalam UUD tahun 1945 pasal 33 ayat 1 yang menyebutkan bahwa perekonomian disusun sebagai usaha bersama berdasarkan atas asas kekeluargaan. Oleh karena itu, sebagai salah satu pelaku ekonomi, koperasi diharapkan mampu menjadi soko guru perekonomian Indonesia (Riani, 2007). Berdasarkan Peraturan Menteri Koperasi dan Usaha Kecil dan Menengah No. 21/Per/M.KUKM/IX/2015 tentang pemeringkatan koperasi menyatakan koperasi berkualitas merupakan koperasi yang mempunyai kinerja baik dalam 5 (lima) ruang lingkup diantaranya: (1). Aspek kelembagaan koperasi; (2). Aspek usaha koperasi; (3). Aspek keuangan koperasi; (4). Aspek manfaat koperasi terhadap anggota; dan (5). Aspek kebermanfaatan kepada masyarakat.

Tidak berkembangnya koperasi disebabkan oleh 2 (dua) faktor, yaitu: adanya kekurangan akan pemahaman terhadap koperasi itu sendiri, kurang memahami jati diri koperasi yang didalamnya terdapat nilai dan prinsip koperasi. Hal ini yang menyebabkan kesalahpahaman dan hilangnya sifat koperasi itu sendiri; serta Pendekatan makro dan politis dalam pembangunan sebuah koperasi, terkadang yang terjadi hanya berputar pada wacana saja. Hal ini diperkuat oleh penelitian yang dilakukan oleh Indriawati et al., (2017), dimana terdapat 7 (tujuh) aspek dalam menentukan tingkat kesehatan sebuah koperasi sehingga koperasi dapat berkembang dengan baik diantaranya: permodalan, kualitas aktiva produktif, manajemen, efisiensi, likuiditas, 
kemandirian dan pertumbuhan, serta jati diri koperasi

\section{Kinerja Keuangan}

Kinerja keuangan merupakan pelaksanaan dalam menganalisis kinerja perusahaan dengan baik dan sesuai dengan aturan yang benar. Terdapat 5 (lima) tahapan dalam menganalisis laporan keuangan diantaranya: (1). Mereview data; (2). Melakukan perhitungan; (3). Perbandingan hasil perhitungan; (4). Penafsiran (interpretation) terhadap permasalahan yang ditemukan; dan (5).
Pemecahan masalah terhadap permasalahan yang ditemukan (Fahmi, 2012). Pengukuran kinerja merupakan faktor yang sangat penting untuk menunjang tumbuh kembang dari suatu koperasi, terutama bagi koperasi yang telah lama berdiri. Berkaitan dengan hal tersebut, koperasi perlu membenahi diri dan harus mampu melihat kondisi lingkungan baik lingkungan internal maupun lingkungan eksternal koperasi.

Menurut Departemen Koperasi (2008), terdapat kriteria penilaian koperasi berprestasi, diantaranya:

Tabel 1

Kriteria penilaian koperasi

\begin{tabular}{|c|c|c|c|c|}
\hline \multirow{2}{*}{ Keterangan } & \multicolumn{4}{|c|}{ Tingkat Prestasi } \\
\hline & Baik Sekali & Baik & Kurang Baik & Tidak Baik \\
\hline \multicolumn{5}{|c|}{ Likuiditas } \\
\hline Current ratio & $175 \%-200 \%$ & $\begin{array}{c}150 \%-174 \% \text { atau } \\
201 \%-219 \%\end{array}$ & $\begin{array}{c}100 \%-149 \% \text { atau } \\
220 \%-239 \%\end{array}$ & $\begin{array}{c}<100 \% \text { atau }> \\
240 \%\end{array}$ \\
\hline $\begin{array}{l}\text { Quick } \\
\text { ratio }\end{array}$ & $180 \%-200 \%$ & $\begin{array}{c}150 \%-175 \% \text { atau } \\
200 \%-220 \%\end{array}$ & $\begin{array}{c}100 \%-150 \% \text { atau } \\
230 \%-240 \%\end{array}$ & $\begin{array}{c}<100 \% \text { atau }> \\
250 \%\end{array}$ \\
\hline $\begin{array}{l}\text { Cash } \\
\text { ratio }\end{array}$ & $10 \%-15 \%$ & $16 \%-20 \%$ & $21 \%-25 \%$ & $\begin{array}{c}<10 \% \text { atau }> \\
25 \%\end{array}$ \\
\hline \multicolumn{5}{|c|}{ Solvabilitas } \\
\hline Total assets to debt ratio & $151 \%-175 \%$ & $\begin{array}{c}121 \%-150 \% \text { atau } \\
>171 \%\end{array}$ & $110 \%-149 \%$ & $<110 \%$ \\
\hline Net worth to debt ratio & $149 \%-165 \%$ & $\begin{array}{c}120 \%-148 \% \text { atau } \\
>165 \%\end{array}$ & $110 \%-119 \%$ & $<110 \%$ \\
\hline \multicolumn{5}{|c|}{ Rentabilitas } \\
\hline $\begin{array}{l}\text { Rentabilitas modal } \\
\text { sendiri }\end{array}$ & $11 \%-20 \%$ & $8 \%-10 \%$ & $5 \%-7 \%$ & $\begin{array}{c}<5 \% \text { atau }> \\
20 \%\end{array}$ \\
\hline Retur on assets & $>10 \%$ & $7,5 \%-10 \%$ & $5 \%-7,5 \%$ & $<5 \%$ \\
\hline
\end{tabular}

Sumber: Peraturan Menteri Negara Koperasi Usaha Kecil dan Menengah (2008)

Pengukuran kinerja yang berorientasi pada masa depan tidak hanya memfokuskan pada aspek keuangan tetapi juga aspek non keuangan. Ukuran keuangan untuk mengetahui hasil tindakan yang telah dilakukan di masa lalu dan ukuran keuangan tersebut dilengkapi dengan ukuran non keuangan seperti kepuasan customer, produktivitas, dan cost effectiveness process business serta komitmen personel yang akan menentukan kinerja keuangan masa yang akan datang. Ukuran keuangan menunjukkan akibat dari berbagai tindakan yang terjadi di luar non keuangan (Himpuni, 2008).

\section{Du Pont System}

Menurut Lianto (2013), du pont system merupakan suatu metode yang digunakan untuk menilai efektivitas operasional perusahaan tersebut, karena dalam analisis ini mencakup unsur penjualan, aktiva yang digunalan serta laba yang dihasilkan perusahaan.

Pengukuran menggunakan analisis $d u$ pont system ini lebih terperinci dikarenakan 
tingkat pengembalian ekuitas berdasarkan margin laba bersih, asset turnover dan equity multiplier. Melalui analisis ini perusahaan dapat memperoleh informasi perihal kinerja keuangan yang fluktuatif. Metode ini sama seperti analisis laporan keuangan pada umumnya, hanya saja pendekatan yang digunakan lebih integrative. Komposisi laporan keuangan digunakan sebagai elemen bahan analisis untuk mengetahui berbagai faktor yang berpengaruh terhadap efektivitas akan pengelolaan sumber daya yang dimiliki perusahaan sehingga segala perencanaan untuk masa depan bisa lebih baik. Analisis ini merupakan gabungan dari beberapa rasio keuangan yakni terdapat rasio aktivitas dan rasio profitabilitas dimana keduanya berperan dalam efekti- vitas dan efisiensi dalam memutar modal perusahaan (Dewi, 2018).

Pengamatan dan identifikasi terhadap formula analisis $d u$ pont system ini dapat dilakukan mengenai kekuatan dan kelemahan serta permasalahan dalam kondisi keuangan secara menyeluruh. ROE yang dihasilkan berasal dari ROI yang dikalikan dengan equity multiplier dimana ROI yang dimaksud berasal dari hasil perkalian antara keuntungan perusahaan dengan perputaran aktiva yang dimiliki oleh perusahaan. Apapun yang dimiliki perusahaan seperti posisi keuangan, kinerja keuangan serta kekuatan keuangan akan diketahui melalui analisis tersebut (Komala, 2013).

Berikut di bawah ini merupakan skema du pont system.

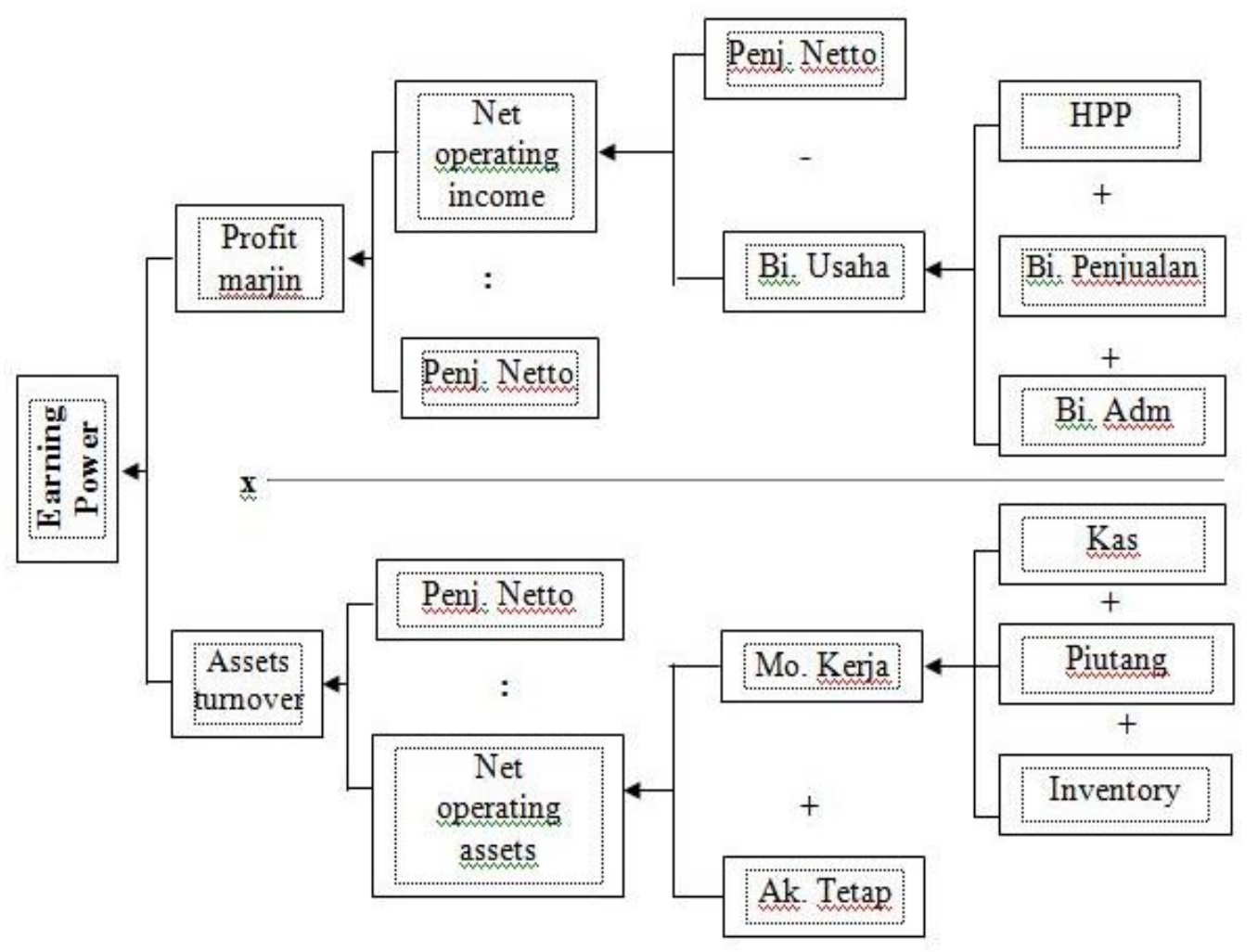

Gambar 1

Du pont system

Menurut Maruta (2018), analisis laporan keuangan dengan menggunakan model $d u$ pont merupakan cara yang lebih sederhana namun sudah mencangkup laporan keua- ngan secara menyeluruh yang meliputi neraca keuangan serta laporan laba rugi. Akan tetapi, analisis ini masih terdapat kekurangannya yakni untuk mendapatkan 
data yang lebih mendetail, maka harus menggunakan metode lain untuk memperolehnya

\section{Penelitian Terdahulu}

Di bawah ini merupakan hasil penelitian terdahulu yang sudah dikerjakan dan berkaitan dengan penelitian yang dilakukan saat ini, diantaranya: penelitian yang dilakukan oleh Tumarjiyanto dan Salman (2014) dimana hasil penelitiannya adalah operating income ratio KUD mampu mengurangi biaya operasinya, rate of return on investmen kemampuan KUD mengelola modal untuk menghasilkan keuntungan kurang baik, kemampuan modal sendiri mengasilkan laba menunjukkan bahwa modal yang dimiliki koperasi tidak cukup solvable dalam menghasilkan kekayaan bersih. Rasio solvabilitas menunjukkan; rasio total hutang dengan modal sendiri, kinerja keuangan KUD kurang solvable dalam memenuhi kewajibannya, rasio total hutang dengan harta, KUD tidak mampu menjamin keamanan bagi kreditur dalam jangka panjang. Rasio likuiditas menunjukkan KUD berada pada kondisi likuid, dan rasio efektifitas KUD Manunggal Abadi masih baik. Rasio harga pokok penjualan atas penjualan, harga pokok penjualan, dan beban operasi atas penjualan masih baik; penelitian yang dilakukan oleh Ramenayanthi et al. (2016) dimana hasil penelitiannya berdasarkan pada hasil analisis keuangan, rasio likuiditas menunjukkan rata-rata rasio saat ini dianggap buruk dan rasio cepat dianggap kurang baik. Rasio solvabilitas menunjukkan rasio utang rata-rata terhadap asset dipertimbangkan buruk dan rata-rata rasio utang terhadap ekuitas dianggap buruk. Rasio aktivitas menunjukkan periode pengumpulan rata-rata dianggap kurang memuaskan, persediaan perputaran dianggap kurang memuaskan, dan perputaran aktiva tetap dianggap sangat bagus. Rasio profitabilitas menunjukkan bahwa margin laba kotor rata-rata adalah dianggap kurang memuaskan, pengembalian aset dianggap kurang memuaskan, dan margin laba bersih dianggap cukup baik. Saran dalam. Penelitian ini adalah bahwa manajemen KUD Mambal harus mempertimbangkan kebijakan untuk mengelola piutang dan inventaris, serta layanan kepada anggota harus ditingkatkan kembali; penelitian yang dilakukan oleh Gevinanda et al. (2017). Dari hasil perhitungan likuditas KUD di Kecamatan Tebing Tinggi mampu menjamin hutang yang dimiliki dengan aktiva lancar dan persediaan, namun KUD tidak mampu menjamin hutang dengan kas dan bank, karena KUD memiliki saldo kas yang kecil. Dari hasil perhitungan rasio solvabilitas menyatakan KUD mampu memenuhi kewajiban jangka panjangnya. Dari hasil perhitungan profitabilitas KUD mampu menghasilkan laba dari usaha yang dijalankan. Dari perhitungan rasio aktivitas KUD memiliki nilai perputaran dana pada persediaan, aktiva tetap dan dana pada piutang yang baik. Peran koperasi bertujuan untuk sejahterakan anggota dengan memberikan manfaat sosial dan ekonomi. Berdasakan hasil penelitian KUD telah memberikan manfaat yang dapat dirasakan oleh anggota dengan baik, namun manfaat yang diberikan KUD Harapan Makmur masih kurang dirasakan oleh anggota, karena kurangnya terjalinnya komunikasi dengan anggota, kurangnya pelayanan, barang-barang yang dijual masih terbatas dan pembagian SHU yang dibagikan belum meringankan beban kebutuhan anggota; penelitian yang dilakukan oleh Himah dan Djaelani (2017), hasil penelitian menunjukkan bahwa harta yang cukup likuid dalam membayar kewajiban jangka pendeknya. Kinerja keuangan yang dapat dicapai berdasarkan hasil analisis tersebut menunjukkan bahwa aktiva lancar yang dimiliki koperasi menunjukkan kriteria yang cukup baik; penelitian yang dilakukan oleh Rahayu (2014), hasil penelitian menyebutkan Rasio likuiditas mengalami perkembangan yang terus meningkat namun berada di bawah $275 \%$, sehingga dapat dinyatakan dalam klasifikasi yang tidak likuid. Rasio solvabilitas (debt to total asset) mengalami fluktuasi 
tetapi angkanya berada di bawah 130\% sehingga dinyatakan dalam kondisi yang baik. Rasio modal sendiri terhadap hutang mengalami kenaikan pada hampir setiap tahun tetapi angka rasio modal sendiri terhadap hutang berada di bawah $15 \%$. Oleh karena itu, dinyatakan dalam klasifikasi yang kurang baik. Rentabilitas Modal Sendiri mengalami fluktuasi tetapi berada di atas 10\%-20\%, maka dinyatakan baik. Sedangkan rasio profitabilitas berada di $1 \%$ sampai 9\%, sehingga dinyatakan dalam klasifikasi yang kurang baik; penelitian yang dilakukan oleh Andani et al., (2015) dimana penelitian ini menggunakan alat analisis berupa analisis rasio keuangan seperti rasio likuiditas, solvabilitas, dan rasio profitabilitas. Hasil penelitian mengemukakan bahwa koperasi ini kinerjanya harus lebih ditingkatkan agar laba yang dicapainya menjadi maksimal serta pelayanan terhadap konsumennya lebih diperhatikan. Adanya penurunan akan rasio solvabilitas ini dapat dicarikan solusinya yang bersumber dari pengurangan utang koperasi; penelitian yang dilakukan oleh Sagala et al., (2012) dimana penelitian ini menggunakan alat analisis berupa analisis BSC (balanced scorecard) yang sesuai dengan judulnya. Hasil penelitiannya dilihat dari berbagai perspektif diantaranya: perspektif keuangan yang menghasilkan rasio likuiditas dan solvabilitas tidak terlalu menguntungkan sedangkan rasio rentabilitas menghasilkan nilai yang baik; perspektif pelanggan dengan tingkat pertumbuhannya masih tergolong belum baik, dari tingkat kepuasan adalah hasilnya puas; dari perspektif proses bisnis internalnya dinilai terjadinya efisiensi; sedangkan untuk perspektif pembelajaran serta pertumbuhan produktivitas karyawan bernilai baik, retensinya mengalami kecepatan dua kali lipat. Dari kesimpulan nilai yang diperoleh, disarankan agar dapat dengan segera menyalurkan dana yang diperolehnya ke setiap unit bisnis. Dilakukan pengamanan yang ekstra ketat, dijalankan secara professional serta menjaga kualitas hingga sampai ke tangan konsumennya merupakan cara koperasi untuk mendistribusikan dana tersebut; penelitian yang dilakukan oleh Kurniawan dan Mulyapradana (2018) dimana penelitian ini mengukur OHC (overhead cost), BOPO (biaya dan pendapatan operasional), ROA (return on assets) dan LDR (loan to deposit ratio) sebuah koperasi sebelum dan sesudah penerapan sistem online. Dimana hasil penelitiannya menunjukkan hasil yang berbeda dengan kondisi sebelum dan sesusah dilakukan online sistem; serta penelitian yang dilakukan oleh Yusuf (2016) dimana dalam penelitian ini alat analisis yang digunakan adalah analisis CAMEL yang telah disesuaikan dengan aspek syariah. Hasil penelitian menunjukkan bahwa koperasi ini adalah koperasi yang cukup sehat dikarenakan terdapat beberapa indikator pengukuran yang tidak mencapai target.

Aspek pengawasan syariah merupakan kekurangannya dan solusinya adalah kualitas SDM yang harus terus ditingkatkan. Dengan kondisi seperti itu, bahwa koperasi ini masih belum professional dan tidak baik dari segi manajemennya

\section{Model Penelitian}

Model penelitian ini dapat digambarkan sebagai berikut:

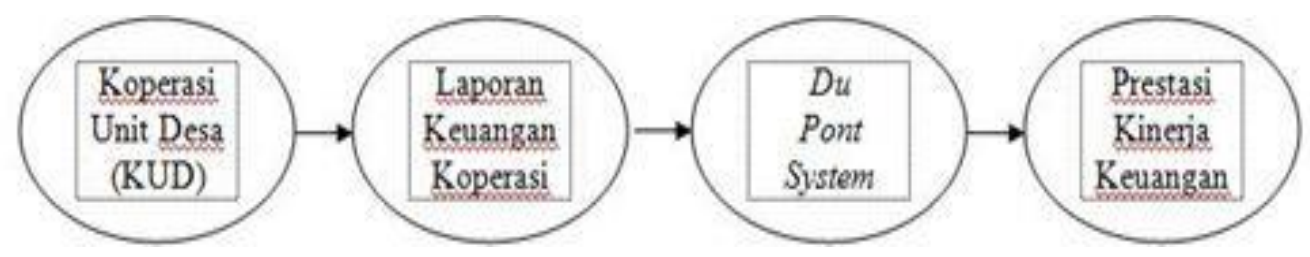

Gambar 2 Rerangka Pemikiran 
Data penelitian ini menggunakan laporan keuangan KUD yang berupa neraca dan laporan laba rugi yang bersumber pada RAT tahun buku 2018 untuk dianalisis. Peneliti menganalisis laporan keuangan KUD tersebut dengan menggunakan analisis $d u$ pont system. Laporan keuangan yang dianalisis berupa neraca dan laporan laba rugi.

Setelah dilakukan analisis pada laporan keuangan KUD tersebut maka peneliti dapat menilai akan prestasi kinerja keuangan KUD dengan menggunakan indikator penilaian tingkat kesehatan koperasi berdasarkan Peraturan Menteri Negara Koperasi Usaha Kecil dan Menengah (2008). Hal ini akan sangat membantu KUD khusunya bagi koperasi yang kinerjanya baik untuk melangkah kedepan dengan gambaran keuangan dan perhitungan yang tepat agar tetap menghasilkan keuntungan yang maksimal demi kesejahteraan anggotanya secara menyeluruh.

\section{METODE PENELITIAN}

Jenis penelitian ini termasuk penelitian deskriptif kuantitatif. Penelitian ini dilakukan untuk mengetahui nilai variabel mandiri, baik satu variabel atau lebih (independent) tanpa membuat perbandingan atau menghubungkan antara variabel satu dengan variabel yang lain.

Kabupaten Pamekasan terdiri dari 13 kecamatan. Dari masing-masing kecamatan tersebut terdapat 1 koperasi unit desa (KUD). Melihat jumlahnya yang sedikit namun menyeluruh, maka hal ini cukup mudah untuk dilakukan. Berikut di bawah ini adalah 13 KUD yang ada di Kabupaten Pamekasan.

Tabel 2

KUD Kabupaten Pamekasan

\begin{tabular}{cll}
\hline \hline No. & \multicolumn{1}{c}{ Kecamatan } & Nama Koperasi \\
\hline 1 & Batumarmar & Sumber Hasil \\
2 & Waru & Setia \\
3 & Pasean & Tunas Harapan \\
4 & Proppo & Sumber Jaya \\
5 & Pamekasan & Sumber Bakti \\
6 & Pagentenan & Karya Harapan \\
7 & Palengnga'an & Harapan Rakyat \\
8 & Pademawu & Dharma Bakti \\
9 & Pakong & Karya Bakti \\
10 & Galis & Guntur \\
11 & Larangan & Karya Sakti \\
12 & Tlanakan & Sumber Wangi \\
13 & Kadur & Karya Kita \\
\hline
\end{tabular}

Sumber: data Dinas Koperasi dan UMKM

Teknik pengambilan sampel pada penelitian ini adalah purposive sampling. Menurut Notoadmodjo (2010), purposive sampling adalah pengambilan sampel yang berdasarkan atas suatu pertimbangan tertentu yang telah diketahui sebelumnya. Berdasarkan batasan masalah yang telah dipaparkan, sampel yang diambil dalam penelitian ini merupakan KUD yang masih aktif baik secara kepengurusan maupun kegiatan atau operasionalnya.

Data diperoleh dengan melakukan observasi langsung terjun ke lapangan. Caranya dengan melakukan wawancara atau meminta data RAT (rapat anggota tahunan) tahun buku 2018 yang diperlukan kepada pihak terkait, baik itu pegawai atau pemilik atau ketua yang melakukan 
pencatatan akuntansi berupa laporan keuangan.

Untuk mengolah data dalam penelitian ini, teknik analisis data yang digunakan oleh peneliti adalah dengan menggunakan analisis $d u$ pont system. Dimana dalam analisis tersebut terdapat 2 (dua) indikator pengukuran diantaranya net profit margin (NPM) dan asset turnover (ATO) yang hasil keduanya menghasilkan earning power. Adapun kedua indikator tersebut dapat dirumuskan sebagai berikut:

$$
N P M=\frac{\text { net operating income }}{\text { penjualan netto }}
$$

Dimana profit margin ini dipergunakan untuk mengukur sejauh mana kemampuan perusahaan dalam memperoleh keuntungan dari setiap produk atau jasa yang dijual oleh perusahaan. Semakin tinggi prosentase hasil perolehan rasio ini maka menunjukkan kinerja rasio ini semakin baik (Murhadi, 2013). Hasil penelitian yang dilakukan oleh Kadir dan Phang (2012), terdapat banyak faktor yang mempengaruhi profit margin yang berasal dari rasio keuangan lainnya diantaranya: Current ratio; Debt ratio; Sales growth; Inventory and receivable turnover ratio; dan Working capital turnover ratio.

ATO $=\frac{\text { penjualan netto }}{\text { net operating asset }}$

Perhitungan asset turnover ini tujuannya untuk mengukur kemampuan seluruh kekayaan (asset) yang dimiliki oleh perusahaan yang dioperasionalkan atau dijalankan dalam upaya mendukung penjualan perusahaan (Sitanggang, 2014).

\section{EarningPower $=N P M \times A T O$}

Analisis $d u$ pont merupakan gabungan dari rasio profitabilitas dengan rasio aktivitas, dimana interaksi antara keduanya menentukan profitabilitas aktiva yang dimiliki perusahaan. Dari analisis tersebut, akan diketahui bahwa KUD tersebut menghasilkan kriteria penilaian koperasi yang baik sekali, baik, kurang baik atau tidak baik. Hasil ini akan bermanfaat bagi manajemen koperasi untuk mengambil langkah konkrit dalam menyelesaikan permasalahan yang ada.

\section{ANALISIS DAN PEMBAHASAN}

Hasil penelitian ini merujuk pada perhitungan rasio keuangan berdasarkan komponen dari analisis $d u$ pont system yang terdiri dari NPM dan ATO. Dimana data untuk menghitung serta menganalisis rasio tersebut bersumber pada laporan keuangan KUD Kabupaten Pamekasan yang berasal dari RAT tahun buku 2018. Selain itu, hasil penelitian ini dapat diketahui bahwa KUD di kabupaten Pamekasan ini yang terhitung masih aktif sesuai Peraturan Menteri No. 21/Per/M.KUKM/IX/2015 hanya tersisa sebanyak 5 (lima) KUD sedangkan 8 (delapan) KUD lainnya sudah tidak aktif lagi. Penelitian lainnya menyebutkan bahwa terdapat 11 KUD di kabupaten Pamekasan yang keberadaannya dalam kondisi sehat (Prasetyowati dan Rofiq, 2016). Ketidak aktifan KUD tersebut dikarenakan banyak penyebab diantaranya salah satunya KUD sudah tidak lagi melakukan RAT secara rutin, dilihat dari aspek kelembagaan koperasi, sudah tidak jelas keberadaannya. Tidak adanya regenerasi yang mumpuni sehingga keberlanjutan koperasi tersebut tidak ada sehingga tidak bisa dilakukan penelitian lebih lanjut, dikarenakan laporan keuangan yang dipergunakan dalam analisis menggunakan $d u$ pont system tersebut sudah tidak terbit atau tidak dibukukan. Adapun KUD yang masih aktif dan sudah tidak aktif di kabupaten Pamekasan tersebut akan tersaji pada tabel di bawah ini:

Adapun koperasi yang tidak aktif tersebut disebabkan banyak faktor dan setiap koperasi berada pada posisi yang berbeda sehingga ini menjadi tugas bagi Dinas Koperasi kabupaten Pamekasan untuk mengaktifkan kembali koperasi tersebut. 
Tabel 3

KUD aktif dan tidak aktif

\begin{tabular}{cll}
\hline No. & \multicolumn{1}{c}{ Nama Koperasi } & Keterangan \\
\hline 1 & Sumber Wangi & Aktif \\
2 & Dharma Bakti & Aktif \\
3 & Karya Sakti & Aktif \\
4 & Karya Kita & Aktif \\
5 & Karya Bakti & Aktif \\
6 & Guntur & Tidak Aktif \\
7 & Sumber Hasil & Tidak Aktif \\
8 & Setia & Tidak Aktif \\
9 & Tunas Harapan & Tidak Aktif \\
10 & Sumber Jaya & Tidak Aktif \\
11 & Sumber Bakti & Tidak Aktif \\
12 & Karya Harapan & Tidak Aktif \\
13 & Harapan Rakyat & Tidak Aktif \\
\hline
\end{tabular}

Sumber: data diolah

Adapun beberapa penyebab sebuah koperasi tersebut tidak aktif diantaranya : (1). Tidak pernah melakukan RAT; (2). Anggota yang kurang dari 20 orang bahkan yang tersisa hanya pengurus inti saja; (3). Lahan tanah untuk bangunan koperasi yang bermasalah; (4). Regenerasi koperasi yang tidak berjalan sehingga koperasi tidak mengalami keberlanjutan; (5). Kurang adanya komitmen yang kuat dari para anggota koperasi terutama pada jenis koperasi simpan pinjam; dan (6). Kurang adanya aturan yang melekat dan kuat sehingga menjadi sebuah peringatan keras terhadap anggota yang "nakal" dan kurang bertanggungjawab akan keberlangsungan hidup koperasi tersebut
Dari hasil tersebut, maka penelitian ini berfokus pada koperasi yang masih aktif dalam melaksanakan pelaporan RAT secara rutin di setiap tahunnya sehingga penulis dapat menganalisis kinerja koperasi tersebut melalui laporan keuangan dengan menggunakan analisis $d u$ pont system yang nantinya dipergunakan untuk langkah selanjutnya dalam pengambilan keputusan ekonomi yang tepat demi keberlangsungan hidup koperasi itu sendiri dan untuk kesejahteraan anggotanya.

Beberapa tabel di bawah ini, akan disajikan indikator perhitungan dari rasio net profit margin pada tahun 2017 hingga tahun 2018, dimana perhitungan tersebut diantaranya:

Tabel 4

Perhitungan Net Profit Margin tahun 2017

\begin{tabular}{|c|c|c|}
\hline Nama Koperasi & NOI & Penjualan \\
\hline Sumber Wangi & $\operatorname{Rp}(4,264,442)$ & $\operatorname{Rp} 66,653,900$ \\
\hline Dharma Bakti & $\operatorname{Rp} 670,954$ & $\operatorname{Rp} 28,670,500$ \\
\hline Karya Sakti & $\operatorname{Rp} 3,144,300$ & $\operatorname{Rp} 31,405,000$ \\
\hline KaryaKita & $\operatorname{Rp}(1,500,800)$ & $\operatorname{Rp} \quad 20,372,000$ \\
\hline Karya Bakti & $\operatorname{Rp}(1,520,248)$ & Rp $99,871,452$ \\
\hline
\end{tabular}

Sumber: data diolah 
Tabel 5

Perhitungan Net Profit Margin tahun 2018

\begin{tabular}{lll}
\hline \multicolumn{1}{c}{ Nama Koperasi } & \multicolumn{1}{c}{ NOI } & \multicolumn{1}{c}{ Penjualan } \\
\hline SumberWangi & $\operatorname{Rp}(4,281,745)$ & $\operatorname{Rp~64,432,450}$ \\
DharmaBakti & $\operatorname{Rp~} 1,864,971$ & $\operatorname{Rp~17,995,403}$ \\
KaryaSakti & $\operatorname{Rp~} 116,403,215$ & $\operatorname{Rp~381,131,000}$ \\
KaryaKita & $\operatorname{Rp~}(2,369,250)$ & $\operatorname{Rp~19,652,100}$ \\
KaryaBakti & $\operatorname{Rp~92,429,826}$ & $\operatorname{Rp~269,053,220}$ \\
\hline
\end{tabular}

Sumber: data diolah

Tabel di atas memberikan gambaran akan perolehan NOI dan penjualan yang diperoleh oleh koperasi, dimana hasil ini akan berpengaruh terhadap perolehan NPM pada tahun 2017 dan 2018. Rasio NPM ini menggambarkan kemampuan penjualan dalam memperoleh keuntungan, yang artinya semakin meningkat rasio ini maka kinerja rasio ini semakin baik. Sehingga, hasil penjualan yang dilakukan oleh koperasi ini akan mempengaruhi kinerjanya dalam perihal NPM ini. Dimana penjualan ini bisa berasal dari penjualan produk bagi koperasi yang bergerak di bidang manufactuing dan berasal dari jasa bagi koperasi yang bergerak dalam usaha jasa. Dalam Tabel 6, dapat dilihat terdapat beberapa koperasi yang mengalami penurunan penjulan dan ada yang mengalami peningkatan perolehan penjualannya dari tahun 2017 ke tahun 2018. Begitu juga dengan NOI pada tahun 2017 ke tahun 2018 terdapat beberapa koperasi yang mengalami penurunan dan ada yang mengalami peningkatan.

Dari data tabel di atas, maka akan diperoleh hasil perolehan dari rasio net profit margin pada tahun 2017 hingga tahun 2018. Adapun hasil tersebut akan disajikan pada tabel di bawah ini:

Tabel 6

Hasil Perolehan Net Profit Margin Tahun 2017

\begin{tabular}{lc}
\hline \hline \multicolumn{1}{c}{ Nama Koperasi } & Profit Margin \\
\hline Sumber Wangi & $-6 \%$ \\
Dharma Bakti & $2 \%$ \\
Karya Sakti & $10 \%$
\end{tabular}

\begin{tabular}{ll} 
Karya Kita & $-7 \%$ \\
Karya Bakti & $-2 \%$ \\
\hline
\end{tabular}

Sumber: data diolah

Tabel 7

Hasil Perolehan Net Profit Margin Tahun 2018

\begin{tabular}{lc}
\hline \hline \multicolumn{1}{c}{ Nama Koperasi } & Profit Margin \\
\hline Sumber Wangi & $-7 \%$ \\
Dharma Bakti & $10 \%$ \\
Karya Sakti & $31 \%$ \\
Karya Kita & $-12 \%$ \\
Karya Bakti & $34 \%$ \\
\hline
\end{tabular}

Sumber: data diolah

Untuk analisis profit margin yang diperoleh oleh KUD yang masih aktif di Kabupaten Pamekasan ini, terdapat 3 (tiga) KUD yang mengalami peningkatan signifikan dari tahun 2017 ke tahun 2018 yakni KUD Dharma Bakti Pademawu, KUD Karya Sakti Larangan dan KUD Karya Bakti Pakong. Terjadinya peningkatan ini disebabkan beberapa faktor diantaranya koperasi mampu menggerakkan roda perekonomian koperasi sehingga penjualan produk yang dimiliki oleh masing-masing koperasi meningkat, selain itu koperasi juga mampu menekan pengeluaran biaya-biaya yang dirasa tidak perlu sehingga terjadi efisiensi dalam pengelolaan koperasi tersebut. Sedangkan 2 (dua) KUD lainnya yakni KUD Sumber Wangi Tlanakan dan KUD Karya Kita Kadur mengalami penurunan pada hasil perolehan profit margin dari tahun 2017 ke tahun 2018. Hal tersebut dipengaruhi oleh beberapa faktor juga diantaranya 
adanya penurunan daya jual produk koperasi yang dalam hal ini adalah produk jasa dikarenakan koperasi ini fokus bergerak pada sektor koperasi simpan. Terjadi tingkat penurunan penjualan dikarenakan banyaknya anggota yang sangat sulit peduli terhadap tanggung jawab yang mereka dalam arti mereka sulit untuk melunasi cicilan hasil dari pinjaman mereka secara on time sehingga hal ini yang menghambat pergerakan koperasi dalam memperoleh keuntungan yang maksimal. Di samping itu, beban yang ditanggung oleh koperasi semakin banyak sehingga tidak sesuai dengan apa yang diperoleh. Hal ini senada dengan hasil penelitian yang dilakukan oleh Kurniansyah (2018), dimana hasil penelitian ini menunjukkan bahwa adanya pengaruh secara simultan antara current ratio, working capital turnover dan debt ratio terhadap NPM namun secara parsial, hanya working capital turnover yang berpengaruh positif terhadap NPM sedangkan variabel lainnya berpengaruh negatif terhadap NPM.

Tabel 8

Perhitungan Assets Turnover

Tahun 2017

\begin{tabular}{lccc}
\hline \multicolumn{1}{c}{ Nama Koperasi } & Penjualan & NOA \\
\hline Sumber Wangi & $R p \quad 66,653,900$ & Rp $1,807,226,822$ \\
Dharma Bakti & $R p ~ 28,670,500$ & Rp $1,112,876,004$ \\
Karya Sakti & $R p ~ 31,405,000$ & Rp $4,572,700,118$ \\
Karya Kita & $R p ~ 20,372,000$ & Rp $425,194,457$ \\
Karya Bakti & $R p \quad 99,871,452$ & $R p \quad 858,447,408$ \\
\hline
\end{tabular}

Sumber: data diolah

Tabel 9

Perhitungan Assets Turnover

Tahun 2018

\begin{tabular}{|c|c|c|}
\hline Nama Koperasi & Penjualan & NOA \\
\hline Sumber Wangi & $\operatorname{Rp} \quad 64,432,450$ & $\operatorname{Rp} 1,712,010,204$ \\
\hline Dharma Bakti & $\operatorname{Rp} 17,995,403$ & $\operatorname{Rp} 1,073,342,790$ \\
\hline Karya Sakti & $\operatorname{Rp} 381,131,000$ & $\operatorname{Rp} 4,754,183,533$ \\
\hline Karya Kita & $\operatorname{Rp} \quad 19,652,100$ & $\operatorname{Rp} \quad 429,778,657$ \\
\hline Karya Bakti & $\operatorname{Rp} 269,053,220$ & $\operatorname{Rp} 1,336,980,854$ \\
\hline
\end{tabular}

Sumber: data diolah

Pada Tabel 8 dan Tabel 9, disajikan indikator perhitungan dari rasio asset turnover pada tahun 2017 hingga tahun 2018, dimana perhitungan tersebut tidak jauh berbeda dengan NPM dimana penjualan berasal dari efektivitas harta yang dimiliki oleh sebuah koperasi agar menjadi keuntungan yang maksimal bagi keberlangsungan hidup koperasi tersebut. Senada dengan hasil perolehan NPM di atas yang dipengaruhi oleh NOI dan penjualan, untuk rasio ATO di bawah ini juga dipengaruhi oleh penjualan dan NOA. Dalam hal ini, pengukuran rasio ini adalah untuk mengukur sejauh mana peran harta yang dimiliki oleh koperasi dalam menghasilkan pendapatan melalui penjualan. Semakin meningkat rasio ini maka semakin baik kinerja rasio ATO tersebut dikarenakan semakin efektif keberadaan harta yang dimiliki oleh koperasi. Dapat dilihat dalam Tabel 8 dan 9, terdapat beberapa koperasi 
yang mengalami penurunan NOA dan ada yang mengalami peningkatan. Hal ini menandakan kinerja koperasi dari tahun 2017 ke tahun 2018 mengalami kinerja yang berbeda dan hal tersebut pula yang akan mempengaruhi kinerja koperasi dari sisi nilai ATO nya. Berikut penyajian perhitungan rasio ATO tahun 2017 hingga ke tahun 2018 dalam bentuk tabelnya

Dari data Tabel 8 dan 9, maka akan diperoleh hasil perolehan dari rasio assets turnover dari semua koperasi yang dianalisis pada tahun 2017 hingga tahun 2018. Hasil ini menunjukkan pengelolaan aktiva atau harta yang dimiliki oleh koperasi dapat dipergunakan untuk menghasilkan keuntungan yang maksimal. Penjualan koperasi juga ikut berperan serta dalam pencapaian tersebut dimana semakin banyak penjualan yang diperoleh maka keuntungan yang diperoleh pun juga sama banyaknya. Adapun hasil tersebut akan disajikan pada Tabel 10 dan Tabel 11.

Tabel 10

Hasil Perolehan Assets Turnover Tahun 2017

\begin{tabular}{lc}
\hline \multicolumn{1}{c}{ Nama Koperasi } & Asset Turnover \\
\hline Sumber Wangi & 0.037 \\
Dharma Bakti & 0.026 \\
Karya Sakti & 0.007 \\
Karya Kita & 0.048 \\
Karya Bakti & 0.116 \\
\hline
\end{tabular}

Sumber: data diolah

Tabel 11

Hasil Perolehan Assets Turnover Tahun 2018

\begin{tabular}{lc}
\hline \multicolumn{1}{c}{ Nama Koperasi } & Asset Turnover \\
\hline Sumber Wangi & 0.038 \\
Dharma Bakti & 0.017 \\
Karya Sakti & 0.080 \\
Karya Kita & 0.046 \\
Karya Bakti & 0.201 \\
\hline
\end{tabular}

Sumber: data diolah
Untuk analisis asset turnover yang diperoleh oleh KUD yang masih aktif di Kabupaten Pamekasan ini, terdapat 3 (tiga) KUD yang mengalami peningkatan yakni KUD Sumber Wangi Tlanakan sedangkan 2 (dua) KUD lainnya yakni KUD Karya Sakti Larangan dan KUD Karya Bakti Pakong mengalami peningkatan yang signifikan di tahun 2018. Hal ini sebuah langkah positif dalam menuju pergerakkan serta perkembangan ekonomi koperasi yang lebih baik untuk meningkatkan kesejahteraan dan perekonomian anggota. Sedangkan untuk 2 (dua) KUD lainnya yakni KUD Dharma Bakti Pademawu dan KUD Karya Kita mengalami penurunan kinerja di tahun 2018.

Dari kedua hasil perhitungan di atas, dapat menghasilkan perhitungan $d u$ pont system yang menggambarkan kinerja koperasi dari segi keuangan dimana hal ini akan berdampak kepada kinerja koperasi secara menyeluruh dikarenakan analisis ini merupakan analisis keuangan yang menggambarkan kekuatan keuangan guna menjalankan operasional koperasi. Salah satu indikator sebuah perusahaan atau koperasi yang sehat adalah terciptanya cerminan perolehan keuntungan yang sehat atau dikatakan pengelolaan keuangannya yang baik. Analisis ini salah satu indikator pengukurannya adalah penjualan sehingga untuk menciptakan kinerja yang baik dalam analisis ini diperlukan optimalisasi dalam melakukan penjualannya. Namun, koperasi tidak hanya berfokus terhadap indikator penjualan saja dikarenakan meskipun menghasilkan penjualan yang banyak namun dalam pengelolaannya kurang tepat maka yang seharusnya menghasilkan keuntungan yang maksimal akan berdampak kepada kurangnya terhadap perolehan keuntungan yang dapat diperoleh. Hal menghambat tersebut diantaranya seperti biaya promosi yang kurang efektif, biaya operasional yang diluar prediksi, pengelolaan harta yang dimiliki tidak tepat sasaran sehingga kurang efektif, biaya lainnya yang diluar dugaan sehingga pengelolaan kurang efisien dan menyebabkan terjadinya kerugian yang 
tidak diharapkan. Hal ini senada dengan hasil penelitian Tere et al. (2014) yang menghasilkan adanya pengaruh secara langsung dan signifikan antara pengukuran aset terhadap kinerja keuangan koperasi

Pada Tabel 12 ini akan disajikan hasil perhitungan akhir dari du pont system yang menggambarkan kinerja keuangan koperasi. Dimana hasilnya sebagai berikut:

Tabel 12

\section{Hasil Earning Power \\ Tahun 2017}

\begin{tabular}{|c|c|c|c|}
\hline $\begin{array}{l}\text { Nama } \\
\text { Koperasi }\end{array}$ & PM & АTO & $\begin{array}{c}\text { Earning } \\
\text { Power }\end{array}$ \\
\hline $\begin{array}{l}\text { Sumber } \\
\text { Wangi }\end{array}$ & $-6 \%$ & 0.037 & $-0.236 \%$ \\
\hline $\begin{array}{l}\text { Dharma } \\
\text { Bakti }\end{array}$ & $2 \%$ & 0.026 & $0.060 \%$ \\
\hline $\begin{array}{l}\text { Karya } \\
\text { Sakti }\end{array}$ & $10 \%$ & 0.007 & $0.069 \%$ \\
\hline $\begin{array}{l}\text { Karya } \\
\text { Kita }\end{array}$ & $-7 \%$ & 0.048 & $-0.353 \%$ \\
\hline $\begin{array}{l}\text { Karya } \\
\text { Bakti }\end{array}$ & $-2 \%$ & 0.116 & $-0.177 \%$ \\
\hline
\end{tabular}

Sumber: data diolah

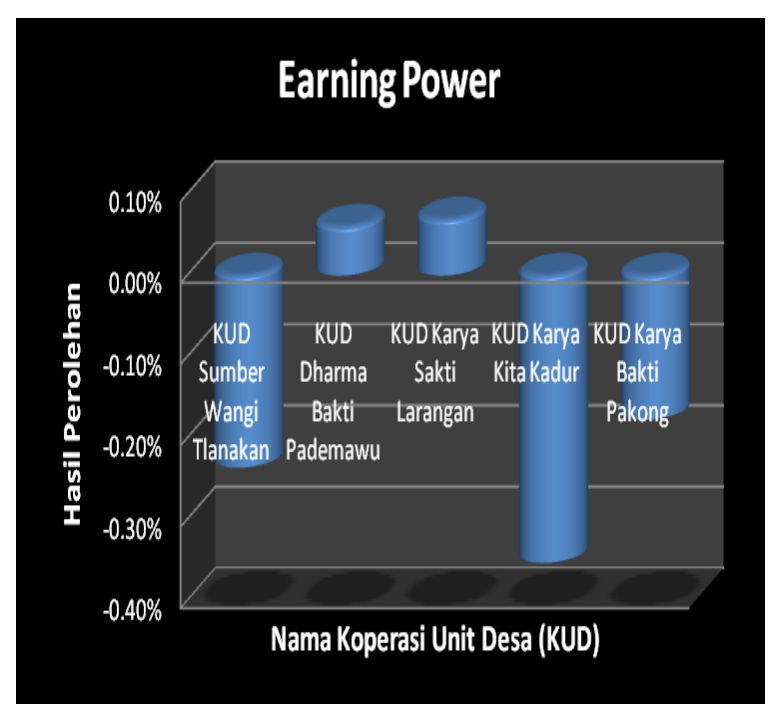

\section{Gambar 3 \\ Earning power Tahun 2017}

Untuk analisis akhir dari penelitian ini yang dianalisis menggunakan $d u$ pont system yang diperoleh oleh KUD yang masih aktif di Kabupaten Pamekasan ini, KUD Karya Bakti Pakong merupakan satu-satunya KUD yang memperoleh hasil yang maksimal di tahun 2018 yakni sebesar 7\% serta 2 (dua) KUD lainnya yang berhasil memperoleh hasil yang baik di tahun 2018 ini yakni KUD Karya Sakti dengan hasil perolehan sebesar 2,4\% dan KUD Dharma Bakti Pademawu dengan hasil perolehan sebesar $0,2 \%$. Hasil tersebut meningkat signifikan dibandingkan dengan tahun sebelumnya. Sedangkan 2 (dua) KUD lainnya yakni KUD Sumber Wangi Tlanakan dan KUD Karya Kita Kadur masih memperoleh hasil yang kurang maksimal di tahun 2018. Secara umum, berdasarkan kriteria penilaian koperasi yang bersumber pada Departemen Koperasi (2008) menunjukkan bahwa prestasi KUD Kabupaten Pamekasan yang masih aktif adalah kurang baik. Hal ini diperoleh dari hasil pencapaian yang diperoleh pada tahun 2018 dimana hasilnya masih berada pada angka $5 \%$ hingga $7,5 \%$. Berikut di bawah ini merupakan hasil perolehan earning power masing-masing KUD pada tahun 2017 hingga tahun 2018.

Terdapat kinerja yang lebih baik jika dibandingkan dengan tahuh sebelumnya, dimana pada tahun 2018 terdapat beberapa koperasi yang menghasilkan hasil perolehan yang meningkat signifikan. Hasil ini menggambarkan bahwasanya beberapa koperasi telah menunjukkan kinerja yang lebih baik dari tahun ke tahun serta dari segi penjualannya yang berdampak kepada meningkatnya hasil perolehan keuntungan koperasi yang juga berdampak kepada hasil perolehan earning power seperti yang tergambarkan pada analisis $d u$ pont tersebut. Hal ini yang merupakan harapan dari berbagai pihak yang mempunyai kepentingan dalam sebuah perusahaan tak terkecuali dalam manajemen koperasi itu sendiri.

Tabel di 13 merupakan gamba- ran hasil dari hasil perolehan eraning power seluruh koperasi yang masih terhitung aktif di wilayah kabupaten Pamekasan pada tahun 2018. 
Tabel 13

Hasil Earning Power

Tahun 2018

\begin{tabular}{lccc}
\hline \multicolumn{1}{c}{$\begin{array}{c}\text { Nama } \\
\text { Koperasi }\end{array}$} & PM & ATO & $\begin{array}{c}\text { Earning } \\
\text { Power }\end{array}$ \\
\hline $\begin{array}{l}\text { Sumber } \\
\text { Wangi }\end{array}$ & $-7 \%$ & 0.038 & $-0.250 \%$ \\
$\begin{array}{l}\text { Dharma } \\
\text { Bakti }\end{array}$ & $10 \%$ & 0.017 & $0.174 \%$ \\
Karya & $31 \%$ & 0.080 & $2.448 \%$ \\
$\begin{array}{l}\text { Sakti } \\
\text { Karya }\end{array}$ & $-12 \%$ & 0.046 & $-0.551 \%$ \\
$\begin{array}{l}\text { Kita } \\
\text { Karya } \\
\text { Bakti }\end{array}$ & $34 \%$ & 0.201 & $6.913 \%$ \\
\hline
\end{tabular}

Sumber: data diolah

Tabel 14

Kinerja KUD Kabupaten Pamekasan Tahun 2018

\begin{tabular}{lcc}
\hline \multicolumn{1}{c}{$\begin{array}{c}\text { Nama } \\
\text { Koperasi }\end{array}$} & $\begin{array}{c}\text { Earning } \\
\text { Power }\end{array}$ & Keterangan \\
\hline $\begin{array}{l}\text { Sumber } \\
\text { Wangi }\end{array}$ & $-0.250 \%$ & Tidak Baik \\
$\begin{array}{l}\text { Dharma } \\
\text { Bakti }\end{array}$ & $0.174 \%$ & Kurang Baik \\
$\begin{array}{l}\text { Karya } \\
\text { Sakti }\end{array}$ & $2.448 \%$ & Kurang Baik \\
$\begin{array}{l}\text { Karya } \\
\text { Kita }\end{array}$ & $-0.551 \%$ & Tidak Baik \\
$\begin{array}{l}\text { Karya } \\
\text { Bakti }\end{array}$ & $6.913 \%$ & Baik \\
\hline
\end{tabular}

Sumber: data diolah

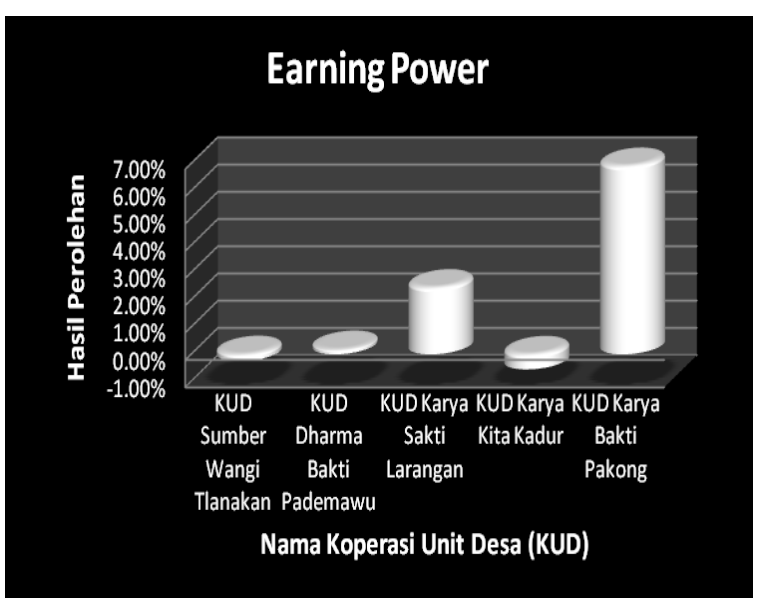

Gambar 4

Earning power Tahun 2018
Tabel 14 tersebut merupakan hasil analisis penelitian secara keseluruhan yang meliputi koperasi aktif di wilayah Pamekasan dimana tabel tersebut menggambarkan kondisi keuangan koperasi aktif tersebut berdasarkan alat analisis dalam penelitian ini yang berupa analisis $d u$ pont system. Tabel 14 tersebut menunjukkan kinerja KUD aktif di wilayah Pamekasan secara menyeluruh dalam menghasilkan kinerja koperasi yang efektif dan efisien dalam memperoleh keuntungan semaksimal mungkin dengan memperhatikan perputaran aktiva atau harta yang dimiliki oleh koperasi tersebut.

Hasil pada Tabel 14 menggambarkan kinerja koperasi dalam perhitungan analisis $d u$ pont yang merupakan kinerja secara umum berdasarkan indikator kinerja koperasi. Dimana dari kelima koperasi yang dianalisis, hanya terdapat 1 (satu) koperasi yang menghasilkan kinerja yang baik yakni koperasi Karya Bakti. Hal ini disebabkan oleh meningkatkanya penjualan yang diperoleh oleh koperasi dari tahun 2017 ke tahun 2018 sehingga menghasilkan perolehan keuntungan yang signifikan, selain itu koperasi tersebut dapat mengelola harta yang dimilikinya dengan efektif sehingga hartanya dikelola dengan baik untuk menghasilkan keuntungan yang maksimal dan pengelolaan biaya yang seefisien mungkin juga diterapkan sehingga tidak merusak atau mengurangi keuntungan yang telah diperolehnya. Hal ini juga dipengaruhi oleh manajemen yang lebih solid daripada manajemen dengan kepengurusan yang sebelumnya, dikarenakan untuk manajemen saat ini diisi oleh generasi mudah atau telah terjadi regenerasi di dalam koperasi tersebut sehingga membuat kinerja manajemen koperasi tersebut mempunyai daya semangat yang lebih dan ini menghasilkan hasil yang signifikan jika dilihat dari hasil perolehan dari tahun 2017 ke tahun 2018 sedangkan untuk koperasi Dharma Bakti dan Karya Sakti merupakan koperasi dengan kinerja yang kurang baik. Meskipun menghasilkan kinerja yang kurang baik, namun 
kedua koperasi ini berbeda kondisinya. Untuk koperasi Karya Sakti kinerjanya sama dengan koperasi Karya Bakti yakni adalah baik, hanya saja jika dibandingkan dengan standar kinerja koperasi maka kinerja koperasi Karya Sakti masih berada dalam indikator kinerja kurang baik. Jika dilihat dari program kerja yang tersusun rapi serta pengelolaan yang baik maka bisa dikatakan kinerja koperasi tersebut untuk tahun selanjutnya bisa lebih baik dan bahkan bisa melebihi dari standar kinerja yang telah ditentukan sebagai indikator kinerja koperasi. Berbeda dengan koperasi Dharma Bakti yang kinerjanya kurang baik di karenakan penjualannya dari tahun 2017 ke tahun 2018 mengalami penurunan sehingga koperasi tersebut menghasilkan keuntungan yang semakin menurun dari tahun sebelumnya atau bisa dikatakan kurang optimal didalam memperoleh keuntungan. Pengelolaan akan aktiva atau harta yang dimiliki oleh koperasi juga kurang efektif dalam pengelolaannya sehingga dalam memperoleh keuntungan untuk keberlangsungan hidup koperasi tersebut kurang maksimal. Hal ini yang menjadi ketidakefektifan di dalam manajemen sebuah koperasi. Begitu juga dengan biaya yang dikeluarkan oleh koperasi, kurang efisien sehingga berpengaruh kepada keuntungan yang diperoleh oleh koperasi. Dimana seharusnya yang dilakukan koperasi disaat kondisi keuntungan kurang maksimal adalah menekan biaya seminim mungkin agar kinerja keuangan tetap stabil. Dengan demikian, kinerja yang dihasilkan oleh koperasi ini adalah kurang baik.

Untuk kedua koperasi dengan kinerja yang tidak baik yakni koperasi Sumber Wangi dan koperasi Karya Kita merupakan koperasi yang tidak sehat dan pengelolaan yang bisa dikatakan jelek dikarenakan dalam mengelola keuangannya hingga menyentuh angka minus. Hasil penelitian yang dilakukan, hal ini disebabkan kedua koperasi ini bergerak dalam usaha koperasi simpan pinjam yang macet sehingga mengakibatkan keuangan koperasi yang tidak stabil. Dalam usaha simpan pinjam, koperasi yang mengalami hal ini akan mengalami kesulitan dikarenakan pihak koperasi akan berhadapan dengan berbagai macam karakter nasabahnya. Hal ini tergambarkan dengan macetnya usaha kedua koperasi sehingga mengakibatkan pendapatan kedua koperasi ini menjadi tidak stabil dan mengakibatkan kinerja koperasi ini dilihat dari analisis $d u$ pont ini adalah tidak baik. Selain itu, yang menjadi kendala adalah tidak adanya pengelolaan manajemen yang baik dari pengurus koperasi yang mengakibatkan hal tersebut terjadi. Hal ini juga menjadi gambaran bagi seluruh organisasi atau perusahaan yang menghasilkan keuntungan, dimana pengelolaan keuangan merupakan bagian yang sangat penting untuk keberlangsungan sebuah organisasi atau perusahaan tersebut dikarenakan segala bentuk kegiatan bisa terlaksana dengan baik dan benar jika ada keuangan yang menyokongnya dengan kondisi yang sehat pula. Selain itu, keberlangsungan hidup organisasi atau perusahaan tersebut sangat bergantung kepada tata kelola keuangan yang akuntabel. Hal ini senada dengan hasil beberapa penelitian yang dilakukan diantaranya oleh Paleni (2016); Kholid et al. (2014) dan Ramenayanthi et al. (2016) dimana hasil penelitiannya yakni kinerja keuangan koperasi adalah kurang baik dari segi perhitungan dengan menggunakan beberapa metode perhitungan keuangan.

Gambar 5 di bawah ini merupakan analisis $d u$ pont koperasi Karya Bakti yang menghasilkan kinerja yang baik dari tahun 2017 ke tahun 2018 sehingga menjadi sebuah gambaran akan kinerja keuangan dengan menggunakan analisis $d u$ pont system di dalam sebuah pengelolaan keuangan koperasi. Dimana hasil analisis $d u$ pont yang diperoleh sebesar 6,913\% dan hasil tersebut merupakan hasil yang meningkat signifikan jika dibandingkan dengan tahun sebelumnya yakni pada tahun 2017 dengan hasil perolehan sebesar $-0,177 \%$, yang artinya kinerja KUD tersebut mengalami peningkatan yang signifikan dari segi keuangannya 
dan hasil tersebut layak untuk dipertahankan bahkan perlu ditingkatkan kembali di tahun selanjutnya mengingat kebutuhan akan kinerja yang baik selalu dibutuhkan dalam persaingan yang kompetitif. Hal ini juga merupakan gambaran bagaimana sebuah koperasi dapat menghasilkan kinerja yang baik dalam menghasilkan penjualan yang baik dan meningkat serta tentunya dengan mengelola harta yang dimiliki oleh koperasi dengan efektif serta menekan biaya seefisien mungkin. Melihat dari hasil perolehan yang diperoleh dari tahun 2017 ke tahun 2018, koperasi ini mengalami kinerja yang signifikan mengingat hasil perolehan yang minus di tahun 2017 meningkat menjadi surplus di tahun selanjutnya yakni 2018. Hasil ini tidak terlepas dari semangat kerja dari pengurus koperasi tersebut yang melihat kinerja koperasi di kepengurusan yang lama kurang baik dalam pengelolaannya.

Program kerja yang ampuh dalam mendatangkan income yang maksimal, kepengurusan manajemen yang baik, biaya yang seminimal mungkin serta pengelolaan aktiva atau harta yang efektif dalam memperoleh keuntungan adalah kunci sukses dalam perolehan koperasi ini dalam meraih hasil kinerja pada tahun 2018.

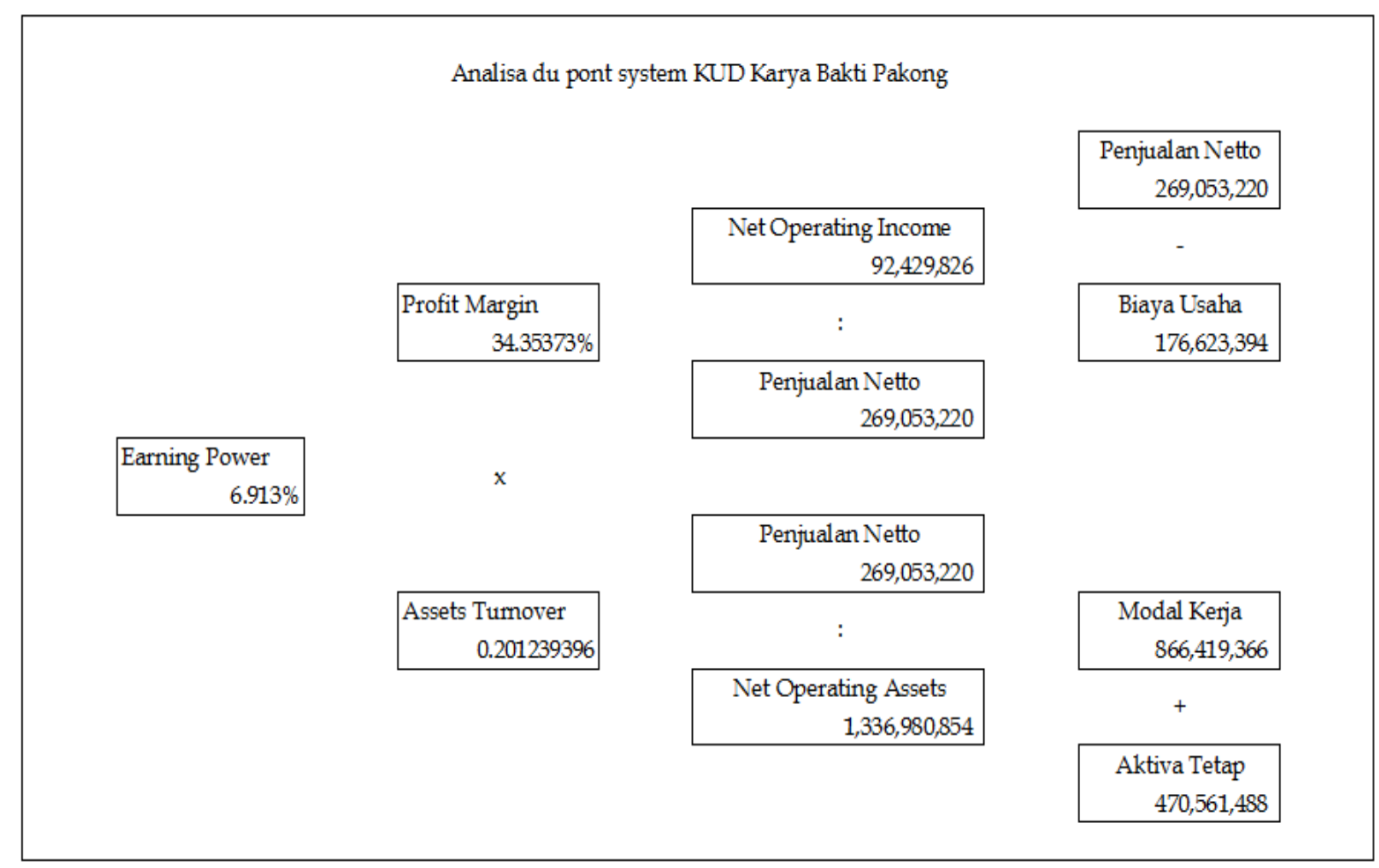

\section{Gambar 5}

Du pont system KUD Karya Bakti Pakong Tahun 2018

\section{SIMPULAN DAN SARAN}

Hasil analisis kinerja KUD dengan menggunakan $d u$ pont system yang tergambar pada Tabel 14, sehingga penulis dapat menarik kesimpulan sebagai berikut: (1) Hasil pencapaian KUD Kabupaten Pamekasan yang masih aktif di tahun 2018 sudah mengalami peningkatan yang cukup signifikan; (2) Adanya usaha yang kuat dari pengurus KUD tersebut secara menyeluruh untuk meningkatkan kinerjanya pada tahun 2018; (3) Tedapat 8 (delapan) KUD yang sudah tidak aktif dan tidak jelas keberlanjutannya; (4) Permasalahan yang melibatkan koperasi dengan warga sekitar dalam hal simpan pinjam harus diselesaikan secara mendetail agar koperasi kembali sehat; serta (5). Secara analisis $d u$ pont yang 
digunakan, menciptakan hasil yang cukup baik secara umum dikarenakan adanya peningkatan prosentase dari indikator pengukuran seperti NPM dan ATO

Adapun saran yang bisa diberikan kepada pengurus KUD dan Dinas yang terkait diantaranya: (1) Untuk meningkatkan kinerja lebih baik di tahun selanjutnya, fokus pada peningkatan penjualan dan efisiensi biaya; (2) Perlu adanya aturan yang jelas perihal koperasi yang bergerak pada sektor simpan pinjam agar pergerakkan ekonomi koperasi dapat berlangsung lebih baik; serta (3). Perlu adanya revitalisasi KUD yang sudah tidak aktif baik dari segi kepengurusan maupun dari segi usahanya sehingga ada kejelasan akan keberlanjutan KUD tersebut.

\section{DAFTAR PUSTAKA}

Andani, L. P. S., I. K. Rantau, dan P. U. Wijayanti. 2015. Analisis Rasio Keuangan Pada Koperasi Unit Desa Panca Satya di Kecamatan Dawan Kabupaten Klungkung. E-Jurnal Agribisnis dan Agrowisata 4(3): 166-174.

Dewi, M. 2018. Analisis kinerja keuangan perusahaan dengan menggunakan du pont system pada PT. Indosat, Tbk. Jurnal Penelitian Ekonomi Akuntansi (JENSI) 2(2): 117-126.

Departemen Koperasi. 2008. Pedoman penilaian koperasi, perusahaan menengah dan kecil berprestasi. Departemen Koperasi Jakarta.

Gevinanda, A. P., Z. Alamsyah, dan S. Nainggolon. 2017. Analisis kinerja keuangan koperasi unit desa di kecamatan Tebing Tinggi kabupaten Tanjung Jabung Barat. Jurnal Ilmiah Sosio Ekonomika Bisnis 20(1): 10.

Fahmi, I. 2012. Analisis Kinerja Keuangan. Alfabeta. Bandung.

Febrinova, R. 2013. Kinerja Keuangan dan Strategi Pengembangan Usaha Koperasi (KUD Usaha Maju Desa Karya Bhakti Kecataman Kampar Kiri). Jurnal Sungkai 1(2): 14-36.
Haryadi dan Rahab. 2006. Analisis Kinerja Koperasi Unit Desa Wilayah Kabupaten Banyumas (Periode Tahun Buku 20012004). Jurnal PERFORMANCE 4(1): 2028.

Himah, D. M. dan A. K. Djaelani. 2017. Analisa Kinerja Keuangan pada Koperasi Serba Usaha "Tunas Setia Baru" Tutur, Nongkojajar Kabupaten Pasuruan Tahun 2013-2015. Jurnal Ilmiah Riset Manajemen 6(06): 1-14.

Himpuni, O. 2008. Analisis Kinerja Koperasi Unit Desa (KUD) Sumber Alam Kecamatan Dramaga Kabupaten Bogor Provinsi Jawa Barat. Skripsi. Program Sarjana Agribisnis Penyelenggaraan Khusus Departemen Agribisnis FEM IPB. Bogor.

Huda, C., R. M. Mardani, dan M. A. Salim. 2017. Analisis Kinerja Keuangan Koperasi Karyawan Melati Husada Malang (Studi Kasus Pada Koperasi Karyawan Melati Husada Malang 2012-2016). Jurnal Ilmiah Riset Manajemen 6(07): 155165.

Indriawati, N., A. Winarno, dan T. Wijijayanti. 2017. Tingkat Kesehatan Koperasi Simpan Pinjam dan Faktor yang Mempengaruhinya. EKOBIS - Ekonomi Bisnis 22(1): 35-43.

Kadir, A. dan S. B. Phang. 2012. Analisis Faktor-Faktor yang Mempengaruhi Net Profit Margin Perusahaan Manufaktur yang Terdaftar pada Bursa Efek Indonesia. Jurnal Manajemen dan Akuntansi 13(1).

Kholid, I., S. M. Rahayu, dan F. Yaningwati. 2014. Penilaian Kesehatan Koperasi Simpan Pinjam Berdasarkan Peraturan Menteri Koperasi dan Usaha Kecil dan Menengah Republik Indonesia Nomor 14/PER/M. KUKM/XII/2009 (Studi pada Koperasi Simpan Pinjam Adi Wijaya Mandiri Kabupaten Blitar). Jurnal Administrasi Bisnis 15(2).

Komala, L. A. 2013. The Effects of Profitability Ratio, Liquidity and Debt towards Investment Return. Journal of Business and Economics 4(11): 1176-1186. 
Kurniansyah, H. 2018. Analisis FaktorFaktor yang Mempengaruhi Net Profit Margin Perusahaan Manufaktur yang Terdaftar pada Bursa Efek Indonesia. GEMA: Jurnal Gentiaras Manajemen dan Akuntansi 10(2): 91-100.

Kurniawan, M. A. dan A. Mulyapradana. 2018. Analisis Kinerja Keuangan Koperasi pada KOSPIN (Koperasi Simpan Pinjam) Jasa Sebelum dan Sesudah Penerapan System Online. JESYA Jurnal Ekonomi dan Ekonomi Syariah 1(1): 51-66.

Lianto, D. 2013. Penilaian Kinerja Keuangan Perusahaan Menggunakan Analisa Du Pont. Jurnal JIBEKA 7(2): 25-31.

Maruta, H. 2018. Analisis Laporan Keuangan Model Du Pont Sebagai Analisis yang Integratif. Jurnal Akuntansi Syariah (JAS) 2(2): 203-227.

Mbae, I. 2013. Analisis Kinerja Keuangan pada Koperasi Simpan Pinjam Pesisir Utama. Jurnal EKOMEN 13(2).

Murhadi, R. W. 2013. Analisis Laporan Keuangan, Proyeksi dan Valuasi Saham. Salemba Empat. Jakarta.

Notoadmodjo, S. 2010. Metodologi Penelitian Kesehatan. Rineka Cipta. Jakarta.

Novianti, M. 2005. Analisis Kinerja Keuangan KUD Mina Sumitra (Studi Kasus KUD Mina Sumitra Karang Lagu Kecamatan Indramayu Kabupaten Indramayu Provinsi Jawa Barat). Skripsi. Fakultas Pertanian Institut Pertanian Bogor. Bogor.

Paleni, H. 2016. Analisis Kinerja Keuangan (Studi Kasus Koperasi Simpan Pinjam "RIAS" P1 Mardiharjo) Kabupaten Musi Waras. Jurnal Ilmiah Orasi Bisnis 16(2).

Peraturan Menteri Koperasi dan Usaha Kecil dan Menengah No. 21/Per/M. KUKM/ IX/2015 tentang Pemeringkatan Koperasi.

Phrasasty, E. I., Kertahadi, dan D. F. Azizah. 2015. Analisis Kinerja Keuangan Perusahaan dengan Menggunakan Du Pont System (Studi Pada PT. Semen Indonesia (Persero), Tbk Periode 2009-2013). Jurnal Administrasi Bisnis (JAB) 2(1).
Prasetyowati, E. dan A. A. Rofiq. 2016. Penilaian Kinerja Keuangan Koperasi Pada Dinas Koperasi dan UMKM Pamekasan dengan K-Means. Jurnal Simantec 5(2).

Rahayu, S. 2014. Analisis Kinerja Keuangan pada KUD Sumber Makmur Kecamatan Tanjung Kabupaten Brebes. PERMANA 6(1).

Ramenayanthi, K. T., I. K. Suamba, dan I. N. G. Ustriyana. 2016. Kinerja Keuangan KUD Mambal di Kecamatan Abiansemal Kabupaten Badung. E-Jurnal Agribisnis dan Agrowisata 5(1).

Riani, E. D. 2007. Kinerja Koperasi Berdasarkan Keputusan Menteri No. 129/ KEP/M/KUKM/XI/2002, Hambatan, Permasalahan dan Implementasinya (Studi Kasus Pada Koperasi Pegawai RI Se Kabupaten Pemalang. Skripsi. Fakultas ekonomi Universitas Negeri Semarang. Semarang.

Sagala, M., M. Antara, dan W. Ginarsa. 2012. Kinerja KUD Ulun Tanjung Desa Kerobokan, Kec. Kuta Utara, Kab. Badung (Ditinjau dari Balanced Scorecard). Journal of Agribusiness and Agritourism 1(2).

Saraswati, D., Suhadak, dan S. R. Handayani. 2013. Analisis Laporan Keuangan Sebagai Alat Penilaian Kinerja Keuangan Pada Koperasi (Studi Pada Koperasi Universitas Brawijaya Malang Periode 2009-2012). Jurnal Administrasi Bisnis (JAB) 6(2).

Sarjana, I. M., K. B. Susrusa, dan D. P. Darmawan. 2013. Analisis Kinerja Keuangan Pada Koperasi Serba Usaha di Kabupaten Buleleng. Jurnal Manajemen Agribisnis 1(2).

Sitanggang, J. P. 2014. Manajemen Keuangan Perusahaan. Mitra Wacana Media. Jakarta.

Soegiarto. 2018. Pengaruh CR, DER, NPF terhadap ROA BMT Nurus Sa'adah di Pekalongan. OWNER: Riset dan Jurnal Akuntansi 2(2).

Tarmizi, R. dan M. Marlim. 2016. Analisis Du Pont System dalam Mengukur Kinerja 
Keuangan Perusahaan (Studi Kasus Pada Perusahaan Telekomunikasi yang Terdaftar di Bursa Efek Indonesia Periode 2012-2014). Jurnal Akuntansi dan Keuangan 7(2): 211-223.

Tere, K., U. Salim, dan A. H. Djawahir. 2014. Pengaruh Ukuran Asset, Piutang, Utang, Modal Sendiri dan Anggota Terhadap Kinerja Keuangan dan Kebijakan SHU (Study Pada Koperasi Kredit Anggota PUSKOPDIT Flores Mandiri). Jurnal Aplikasi Manajemen 12(4).

Tumarjiyanto dan Salman. 2014. Analisis Kinerja Keuangan Koperasi: Studi Kasus Pada KUD Manunggal Abadi di Desa
Tapung Lestari Kecamatan Tapung Hilir Kabupaten Kampar. Jurnal Dinamika Pertanian XXIX(1): 57-68.

Undang-Undang No. 17 Tahun 2012 Tentang Perkoperasian.

Utami, S. B., M. Imron, dan S. R. R. Ardhianie. 2015. Du Pont System Untuk Menentukan Strategi Meningkatkan Kinerja Koperasi (Implementasi Pada KUD Akur Kecamatan Takeran, Magetan). EKOMAKS 4(2).

Yusuf, B. 2016. Analisis Tingkat Kesehatan Koperasi Syariah. Jurnal Bisnis dan Manajemen (ESENSI) 6(1): 101-112. 